Sir,

\section{Response to Chandra and Claoué}

For simultaneous bilateral cataract surgery (SBCS) - as with any intervention - it is essential to ensure that a proper risk/benefit analysis has been performed before introducing this into routine practice.

Chandra and Claoué ${ }^{1}$ set out a 'further advantage' of SBCS; they say that SBCS is additionally beneficial because less road-miles travelled must mean less fatal accidents. Their evaluation of relative probabilities is erroneous. This is well known as the fallacy of the transposed conditional. This is best illustrated by the use of DNA evidence in court ${ }^{2}$ and is well recognized in legal circles as the 'prosecutor's fallacy'. It arises when the prosecution equates a statistical probability with the likelihood of guilt based on the statistical probability. For example, if the frequency of a particular DNA profile is one in a billion and there is a match between the DNA profile of the suspect and the DNA profile of a forensic sample from the crime scene, one way of presenting this would be: 'the chance of obtaining this DNA profile if the DNA in the crime sample came from an individual other than the suspect is one in a billion'. However, this is sometimes - inaccuratelypresented in terms such as the following: 'there is only a one in a billion chance the suspect is innocent'.

It is likely that SBCS patients do not only travel to see their ophthalmologists. It is obvious that cataract patients are on the road for many reasons, and attending their cataract surgery assessment/surgery only forms an insignificant minority of their road-miles, either as driver or passenger. Some may undertake even more hazardous activities.

Our answer to their challenge to your readership 'what is worse?' is that nothing is worse than respected colleagues portraying data in a way that is not logically valid to support their point of view, straying into what the judiciary now refer to as 'Meadows-like' error, and wish to encourage others to follow.

\section{Conflict of interest}

The authors declare no conflict of interest.

\section{References}

1 Chandra C, Claoué C. Simultaneous bilateral cataract surgery: a further advantage. Eye 2010; 24: 1113-1114.

2 UK Parliamentary Publications and Records. http:// www.publications.parliament.uk/pa/cm200405/cmselect/ cmsctech/96/9610.htm (accessed 30 June 2010).

\section{Clearkin and S Prasad}

Eye Department, Arrowe Park Hospital, Wirral, UK E-mail: I.clearkin@liverpool.ac.uk

Eye (2010) 24, 1829; doi:10.1038/eye.2010.142;

published online 15 October 2010 